\title{
Alternative products on the control of asian rust soybean
}

\author{
Produtos alternativos no controle da ferrugem asiática da soja \\ Productos alternativos para el control de la roya asiática de la soya
}

Received: 12/03/2020 | Reviewed: 12/10/2020 | Accept: 12/21/2020 | Published: 01/01/2021

Ivan Carlos Zorzzi

ORCID: https://orcid.org/0000-0003-2355-0323

Simbiose Agro, Brazil

E-mail: ivan.zorzzi@ simbiose-agro.com.br

Mycheli Preuss da Cruz

ORCID: https://orcid.org/0000-0001-8344-6355

Universidade Federal de Santa Catarina, Brazil E-mail: mychelipreuss@ outlook.com

Nean Locatelli Dalacosta

ORCID: https://orcid.org/0000-0001-6465-4503

Coamo Agroindustrial Cooperativa, Brazil

E-mail: nean.locatelli@hotmail.com

Janaína Bruzamarello

ORCID: https://orcid.org/0000-0002-3166-4657

Universidade Tecnológica Federal do Paraná, Brazil

E-mail: janaina.bruzamarello@ hotmail.com

Álvaro Luiz Ghedin

ORCID: https://orcid.org/0000-0001-5800-0992

Universidade Tecnológica Federal do Paraná, Brazil

E-mail: alvaro_ghedin_@hotmail.com

Sérgio Miguel Mazaro

ORCID: https://orcid.org/0000-0003-2787-9409

Universidade Tecnológica Federal do Paraná, Brazil

E-mail: sergio@utfpr.edu.br

\begin{abstract}
In recent years, it has been observed a significant expansion of the organic market. In this context, the main phytosanitary problem of soybean in the organic system is Asian rust (Phakopsora pachyrhizi), for which it is difficult to control, considering the restriction of products authorized for use in the organic system and the limitation of research related to this management system. The objective of this study was to evaluate the effect of alternative products on the germination of uredospores, on the severity of soybean rust on detached leaves and the control of the disease under greenhouse and field conditions. The alternative treatments were calcium silicate, lime sulphur, bordeaux mixture, and copper oxychloride. The variables analyzed were uredospores germination, disease severity, defoliation level, area under the disease progress curve (AUDPC), a thousand grain mass and productivity. The results obtained indicate that there is a possibility of using copper oxychloride to manage the Asian rust in organic production systems. Copper oxychloride had reduced the germination of uredospores and when evaluated under controlled conditions using detached leaves and greenhouse, it had reduced the severity of the disease. In field conditions, copper oxychloride at the doses of 588 and $882 \mathrm{~g}$ ha-1 reduced severity and AUDPC, in addition to increasing productivity at $1434 \mathrm{~kg}$ ha-1 in relation to the control. It is concluded that copper oxychloride can be used as a tool in the management of Asian rust in organic systems of soy production.
\end{abstract}

Keywords: Alternative agriculture; Antimicrobial compounds; Organic systems; Control disease.

\section{Resumo}

Nos últimos anos, tem-se observado uma expansão significativa do mercado de orgânicos. Nesse contexto, o principal problema fitossanitário da soja no sistema orgânico é a ferrugem asiática (Phakopsora pachyrhizi), doença de de difícil controle, considerando a restrição de produtos autorizados para uso no sistema orgânico e a limitação de pesquisas relacionadas a este Sistema de gestão. O objetivo deste trabalho foi avaliar o efeito de produtos alternativos na germinação de uredósporos, na severidade da ferrugem da soja em folhas destacadas e no controle da doença em casa de vegetação e campo. Os tratamentos alternativos foram silicato de cálcio, enxofre de cal, mistura de bordeaux e oxicloreto de cobre. As variáveis analisadas foram germinação de uredósporos, severidade da doença, nível de desfolha, área sob a curva de progresso da doença (AACPD), massa de mil grãos e produtividade. Os resultados obtidos indicam que existe a possibilidade da utilização de oxicloreto de cobre para o manejo da ferrugem asiática em sistemas orgânicos de produção. O oxicloreto de cobre reduziu a germinação dos uredósporos e quando avaliado em condições controladas com folhas destacadas e casa de vegetação, reduziu a severidade da doença. Em condições de campo, o oxicloreto de cobre nas doses de 588 e $882 \mathrm{~g} \mathrm{ha}^{-1}$ reduziu a severidade e a AACPD, além de aumentar a 
produtividade em $1434 \mathrm{~kg} \mathrm{ha}^{-1}$ em relação à testemunha. Conclui-se que o oxicloreto de cobre pode ser utilizado como ferramenta no manejo da ferrugem asiática em sistemas orgânicos de produção de soja.

Palavras-chave: Agricultura alternativa; Compostos antimicrobianos; Sistemas orgânicos; Controle de doenças.

\section{Resumen}

En los últimos años se ha observado una importante expansión del mercado orgánico. En este contexto, el principal problema fitosanitario de la soja en el sistema orgánico es la roya asiática (Phakopsora pachyrhizi), por la cual es difícil de controlar, considerando la restricción de productos autorizados para su uso en el sistema orgánico y la limitación de las investigaciones relacionadas con esta. sistema de gestión. El objetivo de este estudio fue evaluar el efecto de productos alternativos sobre la germinación de uredosporas, sobre la severidad de la roya de la soja en hojas desprendidas y el control de la enfermedad en condiciones de invernadero y campo. Los tratamientos alternativos fueron el silicato de calcio, el azufre de cal, la mezcla de burdeos y el oxicloruro de cobre. Las variables analizadas fueron germinación de uredosporas, gravedad de la enfermedad, nivel de defoliación, área bajo la curva de progresión de la enfermedad (AUDPC), masa de mil granos y productividad. Los resultados obtenidos indican que existe la posibilidad de utilizar oxicloruro de cobre para el manejo de la roya asiática en los sistemas de producción orgánica. El oxicloruro de cobre había reducido la germinación de uredosporas y cuando se evaluó en condiciones controladas usando hojas desprendidas e invernadero, había reducido la severidad de la enfermedad. En condiciones de campo, el oxicloruro de cobre a dosis de 588 y 882 g ha-1 redujo la severidad y el AUDPC, además de incrementar la productividad a $1434 \mathrm{~kg}$ ha-1 en relación al testigo. Se concluye que el oxicloruro de cobre puede usarse como herramienta en el manejo de la roya asiática en sistemas orgánicos de producción de soja.

Palabras clave: Agricultura alternativa; Compuestos antimicrobianos; Sistemas orgánicos; Controlar la enfermedad.

\section{Introduction}

New food consumption patterns by the population have been driving the consumption of organic food in recent years. The new standards are based on the concepts of environment preservation and search for a healthy eating. In this context, the establishment of organic systems for soy production is important to enable activities connected with organic livestock, such as egg, milk and meat production.

Among the organic products with the largest cultivated area and volume of production in Brazil, soybean [Glycine $\max ($ L.) Merrill] has been standing. The planted area in Brazil with grains in the 2018/19 season is 61.5 million hectares, whereas the area destined for organic production is 750,000 hectares (Conab, 2019).

The potential of organic soybean grows along with the tendency of society to seek healthier living habits, with food being one of its main pillars. Cultivation on an organic basis can be seen as a factor of added value to the product, thus enabling increased income from rural properties (Inagaki et al., 2018).

Although we observe the cultivated area expansion in Brazil in organic system in recent years, there is still a lack of information, mainly for grain crops. Among the scarce information are the phytosanitary ones, especially the Asian rust on soybean caused by the fungus Phakopsora pachyrhizi Syd. \& P. Syd. Asian soybean rust is the most devastating disease of soybean, the potential of disease damage is related to premature falling of the leaves and crop cycle reduction due to premature tissue death, conditions that have negatively impact in the productivity (Kashiwa, Muraki, Yamanaka, 2020). These losses can vary from 10 to $90 \%$, depending on climatic conditions and overall crop management (Yorinori et al., 2005). The losses in productivity are related to early defoliation, which compromises the plant formation, grain formation and filling (Godoy et al., 2016).

The importance of the disease increases mainly in crops managed under the organic system, where conventional fungicides are not allowed, condition that limits its control. The class of inorganic fungicides can be divided into copper and sulfuric (Rodrigues, 2006; Frac, 2018), being represented in the organic management by bordeaux mixture, lime sulphur and copper oxychloride.

The bordeaux mixture is produced from the mixture of virgin lime and copper sulphate, which has a fungicidal and bactericidal action when applied in a preventive way (Mazaro et al., 2013). In the literature, significant controls have been reported with the use of bordeaux mixture for potato late blight and downy mildew in grapevines (Gonçalves, 2007; Peruch, 
2008). For the soybean crop, the biweekly use of the bordeaux mixture provided $63 \%$ control of the Asian soybean rust (ASR) in organic production system (Carvalho, 2009). There is also a recommendation for the control of coffee leaf rust (Hemileia vastatrix) and fig rust (Cerotelium fici) (Azevedo, 2003).

The lime sulphur, when applied on the plants, reacts with carbon dioxide and water, generating hydrogen sulfide (H2S) and sulfur colloid (S) (Polito, 2001). When the sulfur penetrates in the cells, it prevents the transport of electrons in the mitochondria, preventing respiration and multiplication of the pathogenic microorganism (Azevedo, 2003). The lime sulphur has been used with certain frequency due to its fungicidal, insecticidal and acaricidal characteristics (Mazaro et al., 2013), mainly in fruit production, fig, apple, vine, persimmon and citrus (Azevedo, 2003).

The copper oxychloride belongs to the group of fungicides with fixed copper compounds, because they present copper ion attached to a stable chemical structure (Azevedo, 2003). In the coffee crop, copper oxychloride is extensively used for crop rust management (Hemileia vastatrix), even in non-organic crops. The use of calcium silicates in disease management can be an alternative, based on the formation of a physical barrier on the leaf surface, that prevents the penetration and development of the pathogen or the deposition of $\mathrm{Si}$ on the internal side of the leaf, which would reduce the penetration and germination of the pathogen (Duarte et al., 2009).

In view of the consideration set out above, there are a limited number of inputs authorized to use in the production of organic soybean, and there are few studies in the literature showing the real efficiency of control of these inputs authorized in relation to the conventional control with chemical fungicides. Thus, the purpose of this study was to evaluate the effect of alternative products on the germination of uredospore's, on the severity of soybean rust in detached leaves and disease control under greenhouse and field conditions.

\section{Metodologia}

The alternative products evaluated are described in Table 1, with the exception of the conventional fungicide, the others have possibility to use in Organic Agriculture, according to the Law $\mathrm{N}^{\circ} 10.831 / 03$, decree $\mathrm{N}^{\circ} 6.323 / 07$ and Normative Instructions 46 of 2011 and 17 of 2014. It is important to emphasize the possibility of use must be authorized by the Organic Conformity Assessment Body (OAC). 
Table 1. Name code, treatment or alternative products, commercial product and concentration evaluated.

\begin{tabular}{|c|c|c|c|}
\hline Code & Treatments & Composition & Doses evaluated* \\
\hline $\mathrm{CS}$ & Calcium Silicate & $\mathrm{P}_{2} \mathrm{O}_{5} 5,4 \% ; \mathrm{Ca} 5,6 \% ; \mathrm{Mg} 4,8 \% ; \mathrm{Si} 8 \%$ & $600 \mathrm{~g} \mathrm{ha}^{-1}$ \\
\hline LS & Lime sulphur & $\begin{array}{l}20 \mathrm{~kg} \text { of sulfur }+15 \mathrm{~kg} \text { of calcium } \\
\text { oxide to } 100 \mathrm{~L} \text { of water }\left(29^{\circ} \text { Bé**) }\right.\end{array}$ & $2 \% * * *$ \\
\hline BM & Bordeaux mixture & $\begin{array}{l}2 \mathrm{~kg} \text { of copper sulfate }+2 \mathrm{~kg} \text { of virgin } \\
\text { calcium oxide to } 100 \mathrm{~L} \text { of water }(\mathrm{pH} \\
7.6)\end{array}$ & $2 \% * * *$ \\
\hline $\mathrm{CO}$ & Commercial copper & Copper Oxychloride $588 \mathrm{~g} \mathrm{~L}^{-1}$ & $\begin{array}{l}\text { 294; } 588 \text { and } 882 \mathrm{~g} \\
\text { ha }^{-1}\end{array}$ \\
\hline $\mathrm{AB}$ & Traditional fungicide & 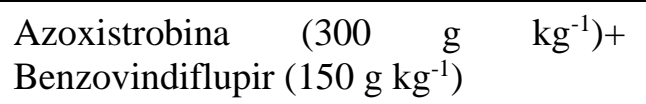 & $200 \mathrm{~g} \mathrm{ha}^{-1} * * * *$ \\
\hline
\end{tabular}

All the tests were carried out with a volume of solution of $150 \mathrm{~L} \mathrm{ha}^{-1} ; * *$ concentration measured with a densimeter; *** concentration to the volume of solution of $150 \mathrm{~L} \mathrm{ha}^{-1}$ and added $0,25 \%$ of vegetal oil; **** Nimbus added to $0,3 \mathrm{~L} \mathrm{ha}^{-1}$. Source: Authors.

The concentrations of the bordeaux mixtures and lime sulphur are based on tests carried out by GEBANA Brazil in partnership with the Federal University of Technology - Parana (UTFPR), Dois Vizinhos campus, where concentrations higher than $2 \%$ had caused phytotoxicity in the soybean crop (Unpublished data).

\subsection{Germination of uredospore's}

The experiment was carried out for studying the effect of alternative products on germination of uredospore in vitro. The uredospores were collected from fresh uredosori from infected plants of soybean.

For the evaluation of the uredospore's germination was prepared a suspension of sterile water in concentration of $1 \mathrm{x}$ $10^{5}$ uredospore's $\mathrm{mL}^{-1}$ measured using Neubauer's chamber. On a glass slide was applied a suspension of 10 microliters ( $\left.\mu \mathrm{L}\right)$ and above it was applied an aliquot of the same volume of the suspension containing sterile water plus the alternative product, with double dose tested. In this study, were evaluated the following treatments: Control, bordeaux mixture and lime sulphur in $2 \%$, copper oxychloride $0,5 \mathrm{~L} \mathrm{ha}^{-1}$ and traditional fungicide, diluted to a $150 \mathrm{~L} \mathrm{ha}^{-1}$ volume of solution.

Subsequently, the glass slides were incubated in BOD (Biochemical Oxygen Demand) for six hours in the dark, under a temperature of $25 \pm 2^{\circ} \mathrm{C}$ and using $10 \mu \mathrm{L}$ of lactophenol to interrupt the germination process (Dorighello et al., 2015). Once the germination process was interrupted, the percentage of germination of uredospore's was evaluated, considering as germinated those uredospore's with germination tubes larger than the spore size. A total of 100 uredospore's were observed randomly, in microscope with a magnification of 100 times (Frac, 2018).

The design was completely randomized with four replicates, each repetition consisting by two counts of 100 spores in one glass slide.

\subsection{Control efficiency in detached leaves}

In a greenhouse, soybean seeds of BRS 284 cultivar were sown in pots filled with substrate. The leaflets were harvested from soybean plants at the reproductive stage. The treatments were applied by immersing the leaves in solution composed of distilled water plus the alternative product for three seconds. In this test was evaluated the following treatments: Control, bordeaux mixture, lime sulphur, copper oxychloride $294 \mathrm{~g}$ ha $^{-1}$ isolated and associated with a source of calcium silicate, calcium silicate isolated and traditional fungicide, diluted to a volume of solution of $150 \mathrm{~L} \mathrm{ha}^{-1}$ and doses according to the Table 1. 
After receiving the treatment, the leaflets were packed in petri dish with abaxial faced up and with filter paper at the bottom to maintain the humidity. After 24 hours, they received a solution of sterile water in a concentration of $1 \times 10^{5}$ uredospores $\mathrm{mL}^{-1}$, applied with manual sprayer .The plates remained in BOD for 15 days, in a photoperiod of 12 hours, temperature of $20 \pm 2{ }^{\circ} \mathrm{C}$ and relative humidity above $60 \%$ (Scherb; Mehl, 2006).

After 15 days of disease inoculation, the severity assessment was performed using the diagrammatic scale proposed by Godoy et al. (2006). The design was completely randomized with four replicates, each replicate consisting of two petri dishes with two leaflets each

\subsection{Efficiency of control under greenhouse conditions}

The experiment was carried out in the period from October 20th, 2016 to February 15th, 2017, in greenhouse with an average temperature of $24{ }^{\circ} \mathrm{C}$ and relative humidity above $65 \%$. In a greenhouse, soybean seeds of BRS 284 cultivar were sown in in 10 liters pots capacity, filled with soil from commercial field and maintained only two plants per pot from V6 vegetative stage.

The treatments were spaced in 15 days, beginning 30 days after sowing, totaling five applications. For the application was used a $\mathrm{CO}_{2}$ sprayer, measured for a 150 liters $\mathrm{ha}^{-1}$ of spray volume. The introduction of the pathogen into the environment was by the application of a suspension containing $4 \times 10^{4}$ uredospores $\mathrm{mL}^{-1}$, one day after the first application of the treatments (Zanatta; Reis; Zanatta, 2012). In this experiment was evaluated the following treatments: Bordeaux mixture, lime sulphur, copper oxychloride $294 \mathrm{~g} \mathrm{ha}^{-1}$ isolated and associated with calcium silicate, calcium silicate isolated, conventional fungicide and control.

The severity evaluations began with the appearance of the first symptoms and subsequently every 10 days, using a diagrammatic scale proposed by Godoy et al. (2006). Three trefoils per plant were evaluated, distributed in the lower, middle and upper thirds and then extrapolated to the overall plant, considering the average of the three values and calculated the area under the disease progress curve (Shaner, Finney, 1977), final severity and control. The design was completely randomized with four replicates, each replicate consisting of one vase with two plants.

\subsection{Control efficiency under field conditions}

The experiment was installed in Planalto - Parana, in the experimental area of GEBANA Brazil, using cultivar BRS 284 , with an initial population of 266,000 ha-1 plants and a spacing of 0,45 meters. The conventional cultivar BRS 284 has an early cycle (maturation group 6.5), an indeterminate growth habit and indicated for cultivation in regions with a maximum altitude of 700 meters. Sowing was performed on October 23th, 2017.

The cultural treatments have followed the recommendations of Normative Instruction 46 of 2011. The fertilization was $400 \mathrm{~kg} \mathrm{ha}^{-1}$ of formulation 07-2.2-08 (composed of fermented poultry manure, natural phosphate and potassium sulphate). For the control of caterpillars, was carried out with two applications of $\mathrm{BtControl}^{\circledR}$ (insecticide based on Bacillus thuringiensis) and weed management with manual weeding.

The applications were spaced in 12 days, starting at 56 days after sowing on 12/18/2017, 12/30/2018, 11/01/2018, $01 / 23 / 2018$ and $02 / 4 / 2018$. The first application was determined by the appearance of the first spores in the spore collectors of the Southwestern region of Parana. An electric sprayer was used to apply the treatments, measured for a volume of 150 liters ha-1. In this test, were evaluated the following treatments: Copper oxychloride 294, 588 and $882 \mathrm{~g} \mathrm{ha}^{-1}$, traditional fungicide and control. The oxychloride was the only alternative product that went to the field evaluation for presenting satisfactory control in the greenhouse test. 
The severity evaluations began with the appearance of the first symptoms and subsequently every 10 days, using a diagrammatic scale proposed by Godoy et al. (2006). Three trefoils per plant were evaluated, distributed in the lower, middle and upper thirds and then extrapolated to the overall plant, considering the average of the three values and the area under the disease progress curve (AUDPC) (Shaner; Finney, 1977), final severity (\%) and percentage of control. The level of crop defoliation was also evaluated, following a scale proposed by Hirano et al. (2010), carried out in a combination with the last evaluation of rust severity in the crop, using the center line of each plot and assigning defoliation severity levels ranging from $5,15,45,65,85$ and $100 \%$.

Variables related to crop yield were also evaluated, obtained by harvesting the useful area of each plot $(4,05 \mathrm{~m} 2)$ : Thousand grain weight (TGW), determined according to the Rules of Seed Analysis (2009), drawing on eight replications of 100 seeds and yield, evaluated by weighing the total grains harvested in the plot area, both variables with humidity corrected to $13 \%$. Due to early defoliation, the treatments were collected on different dates: The control and oxychloride copper $294 \mathrm{~g}$ ha-1 on 03/01/2018 (129 days after sowing), 882 and $588 \mathrm{~g} \mathrm{ha}^{-1}$ on 03/05/2018 (133 days after sowing) and conventional fungicide on $03 / 13 / 2018$ (141 days after sowing).

The experimental design was complete randomized blocks with four replicates, each replicate consisting by plot of six lines by five meters in length $\left(13,5 \mathrm{~m}^{2}\right)$ and useful area in the three central lines with three meters in length $\left(4,05 \mathrm{~m}^{2}\right)$.

\subsection{Statistical analysis}

The results obtained in all the evaluations were subjected to Bartlett's homogeneity of variances test and the normality test of Lilliefors, and when they fit in these assumptions, the analysis of variance (ANOVA) was performed and subsequent Scott Knott's multiple comparison test to 1\%, using the statistical program GENES (Cruz, 2006).

\section{Results and Discussion}

\subsection{Germination of uredospore's}

The germination of uredospore's was affected by the alternative treatments, indicating the potential of some in the ASR control, with no significant difference between treatments with bordeaux mixture (BM), copper oxychloride (CO) and Azoxystrobin + Benzovindiflupir $(\mathrm{AB})$ (Table 2). Lime sulphur treatment did not differ significantly from the control treatment, with no reduction in the percentage of germinated uredospore's.

Hence, was observed a reduction in the germination of uredospore's in the treatments with Azoxystrobin + Benzovindiflupir and copper. 
Table 2. Effect of the alternative treatments on the germination of uredospore's.

\begin{tabular}{ccc}
\hline Treatments & Germination (\%) & Reduction (\%) \\
\hline Control & 85.3 & 0.0 \\
Lime sulphur & 83.8 & 1.8 \\
Bordeaux mixture & 64.0 & 25.0 \\
Copper oxychloride 294 & 58.0 & 32.0 \\
Copper oxychloride 588 & 59.9 & 29.8 \\
Azoxystrobin + Benzovindiflupir & 42.8 & 49.8 \\
\hline Average & 66.8 & - \\
\hline CV (\%) & 15.1 & - \\
\hline
\end{tabular}

Averages followed by equal letters in the columns, do not differ by Scott Knott's test at $1 \%$ probability. Source: Authors.

The ionic copper released in the reaction with water can be immediately accumulated in the membranes of sensitive fungi (Dupont, 2014). After accumulation, it can act chemically when the $\mathrm{Cu}$ ions are taken to the mitochondria, where they will block the respiration, and physically when the spore dehydration occurs, by the formation of microlesions due to the absorption of the copper ions.

On this basis, copper-based compounds should be applied preceding the deposition of the reproduction structures in the host infection sites, thus, will make it possible acting before or during the germination process of the fungus (Reis et al., 2016). This condition must be observed and based on constant monitoring the field and after observed the presence of uredospore's in the case of FAS, the protective fungicide applications should be regular.

\subsection{Experiment on detached leaves}

The treatments with the use of Bordeaux mixture and lime sulphur were not evaluated because they had presented phytotoxicity, a situation that made it difficult to identify and quantify ASR. The severity of FAS in detached leaves at 15 days after inoculation was not affected by calcium silicate, isolated or in combination, indicating a low disease control capacity (Table 3). It has been observed in the literature a superior control with the use of calcium silicate in relation to foliar application, especially due to the amounts absorbed via soil are superior to the foliar application (Lemes et al., 2011; Cruz et al., 2013).

On the other hand, treatments containing copper oxychloride isolated or associated with calcium silicate and Azoxystrobin + Benzovindiflupir did not differ significantly, indicating the potential of copper oxychloride in the control of ARS (Table 3). The application of copper oxychloride preceding the deposition of the spore on the leaf allowed a satisfactory control of the disease. 
Table 3. Effect of alternative treatments on the asian rust severity at 15 days after pathogen inoculation under laboratory conditions.

\begin{tabular}{cccc}
\hline Treatments & Severity (\%) & & Control (\%) \\
\hline Control & 7.62 & a & 0.0 \\
Calcium silicate (CS) & 5.35 & a & 29.8 \\
Copper oxychloride 294 (CO) & 1.80 & b & 76.4 \\
CO+CS & 1.92 & b & 74.8 \\
Azoxystrobin+Benzovindiflupir & 1.43 & b & 81.2 \\
\hline Average & 3.6 & & - \\
\hline CV $(\%)$ & 36.2 & & - \\
\hline
\end{tabular}

Averages followed by equal letters in the columns do not differ by Scott Knott's test at 1\% probability. Source. Source: Authors.

\section{Greenhouse experiment}

The final severity was affected by the alternative treatments and no significant difference was observed between control, calcium silicate source and lime sulphur (Table 4). The isolated bordeaux mixture provided a control of $49.9 \%$ of the ARS, a result lower than that reported by Carvalho et al. (2009) under field conditions, which had observed 63\% control using biweekly applications.

Bordeaux mixture and lime Sulphur are generally difficult to standardize especially if they are stored for long periods, in this way, this lack of standardization can generate different levels of control. The treatments with superior control were copper oxychloride and Azoxystrobin + Benzovindiflupir with 85\% and 91,7\% of control, respectively (Table 4).

Table 4. Final severity (\%), control (\%), area under the disease-progress curve (AUDPC) of soybean plants submitted to different alternative treatments under field conditions.

\begin{tabular}{ccccc}
\hline Treatments & Final Severity $(\%)$ & Control (\%) & AUDPC \\
\hline Control & 63.3 & $\mathrm{a}$ & 0.0 & 788.6 \\
Calcium Silicate (CS) & 55.0 & $\mathrm{a}$ & 13.1 & 708.1 \\
Lime Sulphur (LS) & 53.3 & $\mathrm{a}$ & 15.8 & 436.0 \\
CS+LS & 50.3 & $\mathrm{a}$ & 18.8 & 427.5 \\
Bordeaux mixture (BM) & 31.8 & $\mathrm{~b}$ & 49.9 & 312.0 \\
BM+CS & 38.3 & $\mathrm{~b}$ & 39.6 & 345.8 \\
Copper oxychloride 294 (CO) & 9.5 & $\mathrm{~d}$ & 85.0 & 173.4 \\
CO 294+CS & 15.0 & $\mathrm{c}$ & 76.3 & 175.0 \\
Azoxystrobin+Benzovindiflupir & 5.3 & $\mathrm{~d}$ & 91.7 & 114.1 \\
\hline Average & 33.7 & & 52.6 & 386.7 \\
\hline CV $(\%)$ & 10.1 & & & 12.4 \\
\hline
\end{tabular}

Averages followed by equal letters in the columns do not differ by Scott Knott's test at $1 \%$ probability Data transformed by root of x. Source. Source: Authors.

The effectiveness in the ARS control of copper oxychloride in relation to bordeaux mixture and lime sulphur can be their standardization result of the quality of production and for already contains in its formulation adjuvants, that help in the distribution and fixation of the active ingredient on the leaf.

When we did not observe the addition of CS by foliar application in any of the treatments, an increase in ARS control was noticed (Table 4). The use of potassium silicate (KSi) was not efficient in the control of Asian soybean rust, neither using alone nor in association with the protective fungicides (mancozeb) and systemic (tebuconazole) (Duarte et al., 2009). 
Lemes et al. (2011) has observed reductions of $36 \%$ in the area below the Asian rust progress curve using potassium silicate. This control is possible by the formation of a physical barrier or by the deposition of Si inside the leaf, which would reduce the penetration and development of the pathogen. Other authors suggest that a response to foliar application is generally related to a resistance induction response, with phytoalexins and phenolic compounds production.

The CS treatment did not reduce the area under the disease-progress curve (AUDPC) used as isolated form or when associated with the treatments (Table 4). The lime sulphur and bordeaux mixture differed from the control and from each other, but were less efficient than CO at $294 \mathrm{~g}$ ha-1, which did not differ from Azoxystrobin + Benzovindiflupir. On the basis of what was observed, the copper oxychloride was tested under field conditions, with different doses.

\subsection{Experiment in a field condition}

The copper oxychloride at the dose of $294 \mathrm{~g} \mathrm{ha}^{-1}$ did not differ significantly from the control (Table 5). This lack of the $\mathrm{CO}$ response as a protector at low doses indicates the need for shorter intervals between the applications, trying to minimize losses from storms and lack of protection on new leaves. The ARS control in field conditions for Azoxystrobin + Benzovindiflupir, which was 50,8\%, did not differ significantly from the CO 588 and CO 882 treatments, with a control of 30,7 and $37,3 \%$, respectively.

The control results observed in this study are below those observed in the summarized cooperative trials by EMBRAPA Soybean. The use of 280 and $560 \mathrm{~g}$ ha- 1 of copper oxychloride in five applications resulted in an average control of 40 and 49\% of ARS in 22 trials (Godoy et al., 2015). Silva Junior et al. (2009) using copper oxychloride at a dose of $2520 \mathrm{~g}$ ha-1, had observed a 45\% control, while the chemical treatment (Pyraclostrobin + Epoxiconazole) controlled 73\% of the ARS. However, the authors reported no effect on crop yield.

In spite of the severity and AUDPC did not differ between the two doses of CO and Azoxystrobin + Benzovindiflupir, for defoliation was not observed a significant difference (Table 5). The lowest defoliation observed in treatment with Azoxystrobin + Benzovindiflupir is associated with the ability of strobilurin to minimize ethylene production, which is related to leaf senescence (Reis; Reis; Carmona, 2016).

Table 5. Final severity (\%), control (\%), area under the disease-progress curve (AUDPC) and soybean plants defoliation submitted to different alternative treatments in field condition. Planalto, PR. 2019.

\begin{tabular}{cccccccc}
\hline Treatments & Severity (\%) & $\begin{array}{c}\text { Control } \\
(\%)\end{array}$ & AUDPC & \multicolumn{2}{c}{ Defoliation } \\
\hline Control & 92.0 & $\mathrm{a}$ & 0 & 552.1 & $\mathrm{a}$ & 92.5 & $\mathrm{a}$ \\
CO 294 & 84.1 & $\mathrm{a}$ & 8.6 & 396.0 & $\mathrm{~b}$ & 83.8 & $\mathrm{a}$ \\
CO 588 & 63.8 & $\mathrm{~b}$ & 30.7 & 239.0 & $\mathrm{c}$ & 75.0 & $\mathrm{~b}$ \\
CO 882 & 57.7 & $\mathrm{~b}$ & 37.3 & 210.1 & $\mathrm{c}$ & 70.0 & $\mathrm{~b}$ \\
Azoxystrobin+Benzovindiflupir & 45.3 & $\mathrm{~b}$ & 50.8 & 161.4 & $\mathrm{c}$ & 55.0 & $\mathrm{c}$ \\
\hline Average & 68.6 & & 31.8 & 311.7 & 75.3 & \\
\hline CV $(\%)$ & 19.8 & & & 20.4 & & 13.4 & \\
\hline
\end{tabular}

Averages followed by equal letters in the columns do not differ by Scott Knott's test at $1 \%$ probability. Source: Authors.

For the thousand grain mass and productivity variables, the treatments that received CO 588 and $882 \mathrm{~g} \mathrm{ha}^{-1}$ and Azoxystrobin + Benzovindiflupir differed from each other (Table 6). 
Table 6. Thousand grain mass (TGM), productivity and productivity enhancy of soybean plants submitted to different alternative treatments in field condition. Planalto, PR. 2019.

\begin{tabular}{|c|c|c|c|c|c|}
\hline Treatments & \multicolumn{2}{|c|}{ TMG (g) } & \multicolumn{2}{|c|}{ Productivity $\left(\mathrm{kg} \mathrm{ha}^{-1}\right)$} & Enhance $\left(\mathrm{sc} \mathrm{ha}^{-1}\right)$ \\
\hline Control & 109.8 & $\mathrm{~d}$ & 1609.6 & $\mathrm{~d}$ & 0 \\
\hline CO 294 & 115.3 & $\mathrm{c}$ & 2036.7 & $\mathrm{c}$ & 7.1 \\
\hline CO 588 & 124.8 & $\mathrm{~b}$ & 3086.2 & $\mathrm{~b}$ & 24.6 \\
\hline $\mathrm{CO} 882$ & 123.1 & $\mathrm{~b}$ & 3003.2 & $\mathrm{~b}$ & 23.2 \\
\hline Azoxystrobin+Benzovindiflupir & 133.3 & a & 3358.7 & a & 29.2 \\
\hline Average & 121.3 & & 2618.9 & & - \\
\hline $\mathrm{CV}(\%)$ & 4.2 & & 7.0 & & - \\
\hline
\end{tabular}

Averages followed by equal letters in the columns do not differ by Scott Knott's test at $1 \%$ probability. Source: Authors.

The treatment with Azoxystrobin + Benzovindiflupir provided the highest productivity $3358 \mathrm{~kg} \mathrm{ha}^{-1}$. This improved productivity can be related to the lower anticipated defoliation observed in the traditional fungicide treatment, condition that allowed a prolongation of the grain filling period in relation to the other treatments, as evidenced by the higher TMG.

On the other hand, the treatments that received CO 588 and $882 \mathrm{~g} \mathrm{ha}^{-1}$ had productivities above $3000 \mathrm{~kg} \mathrm{ha}^{-1}$, observing productivity increases with oxychloride applications in relation to the control. This finding is important because several producers of organic soybean do not make applications for disease management in the crop.

\section{Final Considerations}

The copper oxychloride had reduced germination of uredospore's and under controlled conditions using detached leaves and greenhouse had provided satisfactory control of ARS. In field conditions, copper oxychloride at the doses of 588 and $882 \mathrm{~g}$ ha-1 reduced severity and AUDPC, in addition to increasing productivity at $1434 \mathrm{~kg}$ ha- 1 in relation to the control.

It is concluded that copper oxychloride can be used as a tool in the management of Asian rust in organic systems of soy production.

\section{References}

Azevedo, L. D. (2003). Fungicidas protetores: fundamentos para o uso racional. São Paulo, 2.

Carvalho, W. P. (2009). Uso de caldas e biofertilizante no controle da ferrugem asiática da soja em sistema orgânico no Distrito Federal. Revista Brasileira de Agroecologia, 4(2).

Companhia Nacional de Abastecimento (CONAB). (2019). Observatório Agrícola. Acompanhamento da Safra Brasileira de Grãos 2018/19, 6(5), 1 - 125, 2019.

Cruz, C. D. (2006). Programa Genes: Biometria. Editora UFV. Viçosa (MG). 382p.

Cruz, M. F., Rodrigues, F. Á., Diniz, A. P. C., Moreira, M. A., \& Barros, E. G. (2013). Potassium silicate and calcium silicate on the resistance of soybean to Phakopsora pachyrhizi infection. Bragantia, 72(4), 373-377.

Dorighello, D. V., Bettiol, W., Maia, N. B., \& de Campos, R. M. V. B. (2015). Controlling Asian soybean rust (Phakopsora pachyrhizi) with Bacillus spp. and coffee oil. Crop Protection, 67, 59-65. 
Duarte, H. D. S. S., Zambolim, L., Rodrigues, F. D. Á., Rios, J. A., \& Lopes, U. P. (2009). Potassium silicate, acibenzolar-S-methyl and fungicides on the control of soybean rust. Ciência Rural, 39(8), 2271-2277.

Dupont. Kocide WDG. (2014). A evolução do cobre. A importância do cobre na produção cafeeira. Informe Técnico. https://docplayer.com.br/15415540Kocide-wdg-a-evolucao-do-cobre-a-importancia-do-cobre-na-producao-cafeeira-informe-tecnico.html.

Fungicide Resistance Action Committee (FRAC) (2018). Phakopsora pachyrhizi: In vitro agar plate test. http://www.frac.info/.

Godoy, C. V., Koga, L. J., \& Canteri, M. G. (2006). Diagrammatic scale for assessment of soybean rust severity. Fitopatologia Brasileira, 31(1), 63-68.

Godoy, C. V., et al. (2016). Doenças da soja. In: Kimati, H., Amorim, L., Bergamin Filho, A., Camargo, L. E. A., \& Rezende, J. A. M. (1997). Manual de fitopatologia: doenças das plantas cultivadas (Vol. 2). São Paulo: Agronômica Ceres.

Godoy, C. V., et al. (2016). Eficiência de fungicidas para o controle da ferrugem-asiática da soja, Phakopsora pachyrhizi, na safra 2015/16: resultados sumarizados dos ensaios cooperativos. Embrapa Soja. Circular Técnica 119.

Gonçalves, M., Gomes, C., \& Medeiros, C. (2007). Efeito de diferentes caldas e biofertilizantes no controle de requeima (Phytophthora infestans) em batata (Solanum tuberosum L.) sob cultivo orgânico. Revista Brasileira de Agroecologia, Porto Alegre, 2(1).

Kashiwa, T., Muraki, Y., \& Yamanaka, N. (2020). Near-isogenic soybean lines carrying Asian soybean rust resistance genes for practical pathogenicity validation. Scientific reports, $10(1), 1-7$.

Hirano, M., Hikishima, M., Silva, A. D., Xavier, S. A., \& Canteri, M. G. (2010). Validação de escala diagramática para estimativa de desfolha provocada pela ferrugem asiática em soja. Summa phytopathologica, 36(3), 248-250.

Inagaki, M. N., Junqueira, C. P., \& Bellon, P. P. (2018). Desafios da produção de soja orgânica como determinante à implantação de seu cultivo para fins comercias na região oeste do Paraná. Revista Gestão \& Sustentabilidade Ambiental, 7(1), 682-699.

Lemes, E. M., Mackowiak, C. L., Blount, A., Marois, J. J., Wright, D. L., Coelho, L., \& Datnoff, L. E. (2011). Effects of silicon applications on soybean rust development under greenhouse and field conditions. Plant disease, 95(3), 317-324.

Ministério da Agricultura, Pecuária e Abastecimento (Mapa). (2011) Instrução Normativa no 46/11. Estabelece regras para produção orgânica vegetal e animal no Brasil. Brasília, DF.

Mazaro, S. M., Caprini Mangnabosco, M., Citadin, I., Paulus, D., \& de Gouvea, A. (2013). Produção e qualidade de morangueiro sob diferentes concentrações de calda bordalesa, sulfocálcica e biofertilizante supermagro. Semina: Ciências Agrárias, 1(34).

Peruch, L. A. M., \& Bruna, E. D. (2008). Relação entre doses de calda bordalesa e de fosfito potássico na intensidade do míldio e na produtividade da videira cv.'Goethe'. Ciência Rural, 38(9), 2413-2418.

Polito, W. L. (2001). Os fertiprotetores (calda sulfocálcica, calda bordalesa, calda Viçosa e outros) no contexto da trofobiose. Resumos do $1^{\circ}$ Encontro de Processos de Proteção de Plantas: controle ecológico de pragas e doenças. Agroecológica: Botucatu, 75-89.

Reis, E. M., Reis, A. C., \& Carmona, M. A. (2016). Manual de fungicidas: guia para o controle químico de doenças de plantas. Passo Fundo: UPF.

Reis, M. E., Reis, A. C., \& Forcelini, A. C. (2016). Manual de fungicidas: guia para o controle químico de doenças de plantas. rev. e ampl. Universidade de Passo Fundo: Passo Fundo.

Shaner, G., \& Finney, R. E. (1977). The effect of nitrogen fertilization on the expression of slow-mildewing resistance in Knox wheat. Phytopathology, 67(8), 1051-1056. 
Research, Society and Development, v. 10, n. 1, e1110110667, 2021

(CC BY 4.0) | ISSN 2525-3409 | DOI: http://dx.doi.org/10.33448/rsd-v10i1.10667

Scherb, C. T., Mehl, A. FRAC (Fungicide Resistance Action Committee) -Phakopsora pachyrhizi: detached leaf test. 2006. http://www.frac.info/docs/defaultsource/monitoring-methods/approved-methods/phakpa-detached-leaf-monitoring-method-bcs-2006-v1.pdf?sfvrsn=4e9a419a_4>.

Yorinori, J. T., Paiva, W. M., Frederick, R. D., Costamilan, L. M., Bertagnolli, P. F., Hartman, G. E., \& Nunes Jr, J. (2005). Epidemics of soybean rust (Phakopsora pachyrhizi) in Brazil and Paraguay from 2001 to 2003. Plant Disease, 89(6), 675-677.

Zanatta, T., Reis, E. M., \& Zanatta, M. (2012). Adjuvant concentrations and uredospore densities on Phakopsora pachyrhizi infection efficiency in soybean. Summa Phytopathologica, 38(2), 148-151. 